\title{
Beyond $1.5^{\circ} \mathrm{C}$ : vulnerabilities and adaptation strategies for Caribbean Small Island Developing States
}

\author{
Michelle A. Mycoo $^{1}$ \\ Received: 5 June 2017 / Accepted: 25 October 2017 / Published online: 13 November 2017 \\ (C) Springer-Verlag GmbH Germany 2017
}

\begin{abstract}
Global warming of $1.5{ }^{\circ} \mathrm{C}$ above preindustrial levels and a commensurate increase in global greenhouse gas emissions pose an unprecedented danger to human settlements, livelihoods and the sustainable development of Small Island Developing States (SIDS), yet these challenges present tremendous opportunities to rethink development pathways. The paper has two objectives. One is to critically review present vulnerabilities and adaptation strategies employed by the state, private sector, non-governmental organisations, community-based organisations and households. The other is to discuss vulnerabilities and identify adaptation and resiliency strategies which are considered most applicable beyond the $1.5{ }^{\circ} \mathrm{C}$ limit. The Caribbean Region is the focus of the paper. A key finding of the paper is that temperature change above the $1.5{ }^{\circ} \mathrm{C}$ limit set by the Paris Conference of the Parties will make the natural and human systems of SIDS even more highly vulnerable than they are already. Another finding is that Caribbean states have implemented various innovative climate change adaptation strategies, but their relevance should the $1.5^{\circ} \mathrm{C}$ target be exceeded, requires further exploration. The paper is useful to policymakers, decision-makers and finance agencies in search of practical solutions to avert the implications for Caribbean settlements, economies and ecosystems should the temperature warming exceed $1.5^{\circ} \mathrm{C}$.
\end{abstract}

Keywords Caribbean · Small Island Developing States . $1.5^{\circ} \mathrm{C}$ temperature warming $\cdot$ Climate change adaptation . Resiliency $\cdot$ Disaster risk reduction

Michelle A. Mycoo

michelle.mycoo@sta.uwi.edu; mmycoo@hotmail.com

1 Department of Geomatics Engineering and Land Management, The University of the West Indies, St. Augustine, Trinidad and Tobago

\section{Introduction}

Climate change is a formidable challenge to Small Island Developing States (SIDS) which makes them globally the most vulnerable geographical entities and should the $1.5^{\circ} \mathrm{C}$ threshold be exceeded, they will suffer significant social displacement and economic and environmental losses. While the absolute impacts in small islands are quite minimal at a global scale, in relative terms the impacts are the highest. Many Caribbean states raised concerns at COP 15 that a $2{ }^{\circ} \mathrm{C}$ temperature rise was unacceptable as a safe threshold for the protection of small island states and that even a $1.5^{\circ} \mathrm{C}$ increase would undermine the survival of communities (Tschakert 2015). During the Paris Conference of the Parties (COP21) in 2015, SIDS actively participated and supported the global agreement among 195 countries to pursue global action so as to avert dangerous climate change by limiting global warming to well below $2{ }^{\circ} \mathrm{C}$. The agreement highlighted that the international community should aim to reduce the rise in temperature to $1.5^{\circ} \mathrm{C}$ in order to protect island states from the threat of sea level rise (SLR), increased temperatures and rainfall, freshwater decline, decreased food security and coral bleaching. Adapting to climate change and resiliency building under a $1.5^{\circ} \mathrm{C}$ scenario is critical to the sustainable development of SIDS. New, innovative ways in addition to improvements in existing adaptation strategies must be found and rigorously implemented to enhance the capacity of these states to survive exceeding a $1.5^{\circ} \mathrm{C}$ warming level.

Historically, many SIDS served as hinterlands and were created as port cities to facilitate exportation of their natural resources to European metropoles (Mycoo 2014a). Today, approximately 44 million people reside in the Caribbean and more than $50 \%$ of this population lives within $1.5 \mathrm{~km}$ of the coast (Mimura et al. 2007). In some cities, population resides in low-elevation coastal zones (LECZs) located less than $10 \mathrm{~m}$ 
above the sea level. Several SIDS are also experiencing growing levels of informal urbanism where households settle in highly vulnerable locations. In the future, these urbanisation trends will have significant implications for adaptation strategies pursued in response to the $1.5^{\circ} \mathrm{C}$ target. Economic costs will be a major concern for SIDS especially because the cost of damage to critical infrastructure that supports human settlements will be even greater, and the cost of rising sea levels as a percentage of the gross domestic product (GDP) will be high relative to the small size of SIDS economies. The Caribbean is important economically so that reaching a temperature beyond the $1.5^{\circ} \mathrm{C}$ warming level will have serious implications. Impacts may include a decline in national output, inflation, increasing debt, revenue loss, employment decline and higher poverty levels. Furthermore, if the $1.5^{\circ} \mathrm{C}$ warming level is surpassed, natural ecosystems will be further endangered and water and food security will be even more threatened by rising temperatures and drought.

SIDS have not been inactive in responding to climate change challenges but rather have been innovative in reacting to impacts. All three adaptation approaches of protect, accommodate and retreat have been employed with varying degrees of success. In particular, the donor community has responded positively to the challenge of adapting to climate change in SIDS. It has provided US $\$ 55.6$ billion in Official Development Assistance to Caribbean and Pacific SIDS between 1995 and 2015 nearly doubling average annual aid flows (in current prices) (Mycoo and Donovan 2017). The Caribbean has also leveraged green climate funding and secured US\$460 million in green finance. However, should there be $1.5{ }^{\circ} \mathrm{C}$ warming level beyond preindustrial levels, SIDS will need to revisit the appropriateness of adaptation strategies and will need to access additional climate funding to implement revised strategies and context-specific measures. Moreover, they will need to focus more on building resilience to attain sustainable development. These challenges facing SIDS should not be viewed as formidable; they are really opportunities for transformational adaptation.

This paper focuses on Caribbean SIDS and two main questions are framed: (i) What are the projected vulnerabilities and impacts beyond a warming of $1.5^{\circ} \mathrm{C}$, and (ii) which adaptation methods are applicable should a warming beyond $1.5^{\circ} \mathrm{C}$ occur? The paper firstly investigates projected climate change impacts and vulnerabilities in the region. Secondly, it proposes the most applicable adaptation and resiliency strategies and measures to minimise the vulnerability of settlements, ecosystems and the economy if temperature warming crossed $1.5^{\circ} \mathrm{C}$. Finally, the paper presents the main conclusions as to the way forward.

An extensive review of evidence-based vulnerabilities in Caribbean SIDS was conducted to establish climate change impacts below the $1.5^{\circ} \mathrm{C}$ threshold. This was based on peerreviewed journal articles, grey literature including reports of regional governments, regional institutions and international development agencies. Most of the literature review focused on Caribbean SIDS.

\section{Vulnerabilities and impacts beyond $1.5^{\circ} \mathrm{C}$}

The Caribbean's human settlements, climate-sensitive economic sectors and rich biodiversity are already highly impacted by climate change. If globally countries are unable to meet the target of keeping temperatures below a $1.5{ }^{\circ} \mathrm{C}$ threshold, the vulnerability of Caribbean SIDS will be exacerbated and impacts are likely to be even more acute. Studies linking vulnerabilities, impacts and adaptation in the context of exceeding $1.5^{\circ} \mathrm{C}$ are limited because it was as recent as 2015 at the Paris (COP21) meeting that Caribbean SIDS raised alarm about their survival if there was a temperature warming beyond $1.5^{\circ} \mathrm{C}$. As a result, studies used for reference in this paper are not all linked to a $1.5{ }^{\circ} \mathrm{C}$ threshold. Instead, this section of the paper discusses the types of vulnerabilities and impacts which exist and how they may be exacerbated beyond a $1.5^{\circ} \mathrm{C}$ temperature increase.

Under all Representative Concentration Pathways scenarios, the rate of SLR will very likely exceed that observed between 1971 and 2010 due to increased ocean warming and increased loss of mass from glaciers and ice sheets (Church et al. 2013). The annual projected change in sea level between two time periods nearly 100 years apart (1986-2005 and 2081-2100) is 0.5 to $0.6 \mathrm{~m}$ in the Caribbean (Nurse et al. 2014). More recent estimates show a trend in the relative SLR for the coastal zones in the Caribbean East as $3.5( \pm 3.22) \mathrm{mm}$ per year and the Caribbean Sea $2.0( \pm 3.14) \mathrm{mm}$ (Rietbroek et al. 2012). These projected trends may have significant impact on population, infrastructure and coastal ecosystems.

Rainfall records averaged over the Caribbean region for 100 years (1990-2000) show a consistent $0.18 \mathrm{~mm} \mathrm{yr}^{-1}$ reduction in rainfall, a trend that is projected to continue (Jury and Winter 2010). Climate model projections of the Caribbean of 1 to $4{ }^{\circ} \mathrm{C}$ showed that drier conditions in the south of the Caribbean with a strong tendency to drying in the traditional wet season from June to October will occur, as well as, lengthening seasonal dry periods and increasing frequency of drought, increasing demand for water throughout the region (Nurse et al. 2014).

Between 1950 and 2014, natural disasters cost the region approximately US\$53billion in damages (Centre for Research on the Epidemiology of Disasters 2015). Nearly one in ten disasters causes damages costing over $30 \%$ of Caribbean SIDS' GDP, compared to less than 1\% of GDP in larger countries (IMF 2016). Scientists warn that while the overall frequency of Atlantic storms may decrease, the intensity of the hurricanes is likely to increase. Additionally, projections indicate that the global average sea level is set to rise by 254 to 
$812 \mathrm{~mm}$ in the coming century (Church et al. 2013). As a result, for low-lying Caribbean SIDS such as the Cayman Islands, the Bahamas and Suriname, this rise will be devastating if these countries are unable to adapt. The projected rise in sea level and severe storms are likely to increase the risk of storm surges and will further negatively impact biodiversity, settlements and infrastructure.

A study by Schleussner et al. (2016) revealed that as a result of a $1.5{ }^{\circ} \mathrm{C}$ temperature increase, SIDS hotspots will suffer a substantial and rapid increase in climate change risks which include risks for unique and threatened systems such as coral reefs and risks by extreme events. This change will be significant because of limited adaptive capacity and high exposure.

\section{Human settlements vulnerability beyond $1.5^{\circ} \mathrm{C}$}

If the $1.5^{\circ} \mathrm{C}$ scenario is exceeded, many Caribbean SIDS coastal cities will be prone to more severe flooding due to subsidence and SLR, even if adaptation investments maintain constant flood probability (Hallegatte et al. 2013). Four of the world's top ten cities located in the LECZ are in the Caribbean: the Bahamas, Suriname, Guyana and Belize. The population concentrated in these cities is as high as $88 \%$ and over, for example, the Bahamas (100\%), Suriname (76\%) and Guyana (55\%). In Caribbean SIDS, six of 15 coastal capitals contain more than $50 \%$ of the country's population, and as noted earlier, approximately a half of the region's population lives within $1.5 \mathrm{~km}$ of the shoreline. In most SIDS coastal cities, current defences against storm surges and flooding are designed to withstand only existing conditions, and critical infrastructure are vulnerable. Many human settlements, including Georgetown (Mycoo 2014a) and Port of Spain, have urban infrastructure deficits such as a lack of drainage and wastewater treatment facilities which increase health risks. The growing percentage of persons living in informal settlements with substandard housing and which lack basic infrastructure will be significantly impacted by a temperature increase of $1.5^{\circ} \mathrm{C}$ and beyond. In human settlements, protection and preparation are very important if the $1.5{ }^{\circ} \mathrm{C}$ target is surpassed. A devastating flood in the main city will cause economic collapse. These incidences will have adverse effects, especially in times of disasters when such infrastructure is vital for relief, supply and other essential functions. The future protection of these cities, towns and villages requires substantial investment in structural defences and better planning.

\section{Health impacts}

Exceeding the $1.5^{\circ} \mathrm{C}$ target is expected to increase health risks in the most vulnerable communities of SIDS where the burden is already high (World Health Organisation 2016). Higher temperatures are expected to adversely affect the health of some island inhabitants who already suffer through heat waves and associated increased outbreaks of vector-borne diseases including dengue (World Health Organisation 2016) and Zika. 'Increasing temperatures, sea-level rises, changes in precipitation patterns and extreme events are expected to increase a range of health risks, from the direct effects of heatwaves, floods and storms, to more suitable conditions for the transmission of important infectious diseases, to impacts on the natural systems and socioeconomic sectors that ultimately underpin human health' (Neira and Galvão 2013, p. 5). Additionally, a lack of safe water may compromise hygiene and increase the risk of diarrhoeal disease (World Health Organisation 2016). Projected effects on national economies associated with the population stricken by disease outbreaks include lower labour productivity and stress on already overburdened public health systems in the Caribbean.

Earlier studies confirmed threats to health posed by extreme weather events in the Caribbean included insect- and rodent-borne diseases, foodborne diseases, respiratory diseases, heat-related illnesses, malnutrition and anxiety and stress (Ebi et al. 2006).

\section{Economic vulnerability beyond $1.5^{\circ} \mathrm{C}$}

SIDS are heavily dependent on climate-sensitive economic sectors such as tourism, agriculture and fisheries and if the $1.5^{\circ} \mathrm{C}$ temperature warming was crossed, economic vulnerability will increase even more. Gross revenues generated by the Caribbean's blue economy are an estimated US $\$ 407$ billion (as of 2012) (Patil et al. 2016). The economic impact of increased hurricane damage, loss of tourism revenue and infrastructure damage are projected to total US $\$ 22$ billion annually by 2050 and US\$46 billion by 2100 (Bueno et al. 2008), but this estimate did not include a temperature change of $1.5^{\circ} \mathrm{C}$ beyond preindustrial levels. Current economic models grossly underestimate climate change impacts (Stern 2016). Exceeding the $1.5^{\circ} \mathrm{C}$ target will greatly increase these estimations. This section critically reviews the vulnerability of the Caribbean's blue economy if the $1.5^{\circ} \mathrm{C}$ target is surpassed.

\section{Tourism}

Caribbean SIDS are highly reliant on the tourism sector since it is a major contributor to the GDP of most islands. Tourism accounts for $77 \%$ of Antigua and Barbuda's GDP, $48 \%$ of the Bahamas's GDP and 39\% of Barbados' GDP (World Travel and Tourism Council (WTTC) 2015). In 2013, the Caribbean tourism sector contributed US $\$ 49$ billion to the region's economy and directly sustained 1.1 million jobs (WTTC 2015). Climate change is projected to exacerbate existing development challenges such as fresh water supply and infrastructure resilience to storms, indicating the need for the tourism 
industry to adapt (Scott et al. 2016a). Studies confirm, however, that SLR associated with climate change is eroding beaches and warmer temperatures are making the region less attractive to tourists because of heat waves (Shakeela and Becken 2015; Mahon et al. 2013). Also, increased frequency and intensity of hurricanes and storms affects the image of the Caribbean as a safe destination. If $1.5{ }^{\circ} \mathrm{C}$ temperature warming is crossed, the damage to tourism assets may be significant and tourists may visit other less vulnerable destinations.

Tourism revenue for the Caribbean is projected to increase by over US $\$ 70$ billion per year by 2024 (WTTC 2015), but it is estimated that if current climate change trends continue, increased hurricane damage, loss of tourism revenue and infrastructure damage could total US $\$ 22$ billion a year by 2050 and US $\$ 46$ billion by 2100 (Simpson et al. 2012). SLR and a $1.5^{\circ} \mathrm{C}$ temperature increase would undermine coastal tourism in the region, with implications for property values, insurance costs, destination competitiveness, marketing and wider issues of local employment and economic well-being for thousands of employees. These impacts could prove to be economically disastrous to Caribbean economies. An estimated $60 \%$ of Grenada's beaches would disappear in some areas if temperatures exceeded the $1.5^{\circ} \mathrm{C}$ threshold causing SLR to rise as little as $50 \mathrm{~cm}$ (Scott et al. 2012). The imposition of a projected SLR of $1 \mathrm{~m}$ on topographic maps revealed approximately 49 to $60 \%$ of the Caribbean's tourist resorts would be damaged (Scott et al. 2012). An analysis of 673 major resorts surveyed in the Caribbean Community (CARICOM) countries indicated that $149(22 \%)$ were at risk to 1-m SLR. Even more tourist resorts will be affected by higher levels of SLR associated with going beyond the $1.5{ }^{\circ} \mathrm{C}$ temperature warming. Risks are especially high for some islands such as Barbados where about $80 \%$ of the hotels are located within $250 \mathrm{~m}$ of the high water mark, and its larger hotels are generally located within the LECZ which places them at risk to SLR and storm surges. With $80 \%$ of the land lying less than $1 \mathrm{~m}$ above sea level, all sectors in the Bahamas are highly vulnerable and the tourism industry could face annual losses of almost US $\$ 900$ million by 2050 .

Higher temperatures will have an impact on the operating costs of tourism operators, such as insurance, heatingand-cooling costs, pest management and the need to augment the water supply for drinking and irrigation needs. Of significant importance to tourism will be the effects of extreme events on infrastructure and insurance costs. The Association of British Insurers suggests that insurance premiums for the Caribbean region could increase by 20 to $80 \%$ by mid-century. Private sector insurance coverage may no longer be available in particularly high-risk areas, forcing governments to provide insurance for tourism development or causing the retreat of development from these areas (Simpson et al. 2011).
Shipping and trade

Port cities will suffer major damage if the $1.5^{\circ} \mathrm{C}$ temperature warming is passed. Some countries have embarked on port expansion and upgrading although investments may be made more vulnerable under a $1.5^{\circ} \mathrm{C}$ and beyond scenario. In the northern Caribbean, SLR could be 25\% higher than the global average due to other physical factors affecting land elevation (Simpson et al. 2011). As much as $3108 \mathrm{~km}^{2}$ of Caribbean coastal land will be lost due to SLR, and a 1-m SLR will inundate a total of 21 out of $64(32 \%)$ airports within CARICOM and this figure may be higher if the $1.5^{\circ} \mathrm{C}$ threshold is exceeded (Simpson et al. 2011).

It is predicted that a SLR of $1 \mathrm{~m}$ and above will inundate surrounding port lands of $80 \%$ of CARICOM ports unless protected by coastal structures. The mayors, urban planners and engineers of port cities in the region should be cognisant of the enormous costs and implications of SLR, hurricanes and coastal storms to port infrastructure. Potential impacts to coastal infrastructure such as ports, harbours and marinas include increased dredging and higher maintenance costs.

Port cities such as Port of Spain (Trinidad), Kingston (Jamaica), Georgetown (Guyana), Nassau (Bahamas) and Paramaribo (Suriname) are already affected by SLR as well as flooding which may worsen with temperature trending higher. Among the leading port cities with the greatest increase in risk is Santo Domingo, Dominican Republic (Hallegatte et al. 2013). Despite investment in upgrading and expanding these old ports into containerised ports, they remain susceptible to losses during flood events. A temperature increase of $1.5^{\circ} \mathrm{C}$ could make Caribbean ports highly vulnerable to SLR and flooding and severely reduce shipping and trade.

\section{Agriculture and fisheries}

Climate change presents a growing threat to food security in the Caribbean with differing rainfall patterns, water scarcity, heat stress and increased climatic variability making it difficult for farmers to meet demand for crops and livestock. The Caribbean accounts for seven of the world's top 36 water-stressed countries, with Barbados in the top ten. The region is expected to experience an increase in intensity and frequency of droughts and this may be exacerbated by a temperature increase of $1.5{ }^{\circ} \mathrm{C}$ above pre-industrial levels. Evidence of these climate change impacts are found in examples such as the prolonged drought in Jamaica which affected over 18,000 farmers and caused the agricultural sector to suffer a loss of US\$7.7 million (Government of Jamaica 2015).

The fisheries sector of Caribbean SIDS is an important source of livelihood for approximately 182,000 people who 
directly depend on these resources (International Union for the Conservation of Nature 2015). Fisheries in the region earn approximately US\$5 billion to US\$6 billion per year in foreign exchange (Nurse 2011). The Caribbean's fisheries sector is significantly affected by climate change such as warming sea temperatures, storms and hurricanes that are causing damage to coral reefs which are nurseries for hatchlings. Declining fish stock in the region is recorded due to natural hazards and anthropogenic factors such as coastal water pollution, snorkelling and diving. Given the economic and environmental importance of the fisheries sector in the Caribbean, a $1.5^{\circ} \mathrm{C}$ temperature increase may cause a spike in warm water temperatures and increased frequency in natural disasters which would result in extensive coral reef damage and reduction of the fishing stock. Furthermore, the warming waters will drive fish away from the equator, thus, further diminishing the overall fish population in the Caribbean. If there is no action to reduce these impacts, permanent fishing camps on low lying offshore cays may be completely submerged by future sea level rise. An increase to $1.5^{\circ} \mathrm{C}$ would cause irreparable damage to the fisheries sector in the Caribbean.

\section{Informal economy}

Caribbean economies are dichotomised into a formal and informal sector. The informal sector has grown because of increasing joblessness, reduction in public sector jobs and economic crises that result from downturns in the economy in the aftermath of hurricanes and storms. It ranges from 15 to $50 \%$ across the region; however, given the recent economic downturn, these figures may be higher. In the early 2000s, the size of the informal economy varied from as low as $15 \%$ of the Bahamas' GDP, 22\% for Jamaica, over $40 \%$ for Belize, St. Lucia and St. Vincent and the Grenadines (International Monetary Fund (IMF) 2008) and Trinidad and Tobago in 2014 was 26 to $33 \%$ (Peters 2017).

Climate change is already impacting negatively on the informal sectors because the livelihoods of small communities that are dependent on coastal resources such as fisheries and tourism are quite vulnerable to climate change. The informal economy is likely to suffer significantly as small-scale operators will be unable to withstand the shock of temperature change beyond the $1.5{ }^{\circ} \mathrm{C}$ limit. Many persons in the informal tourism sector will be affected including women vendors at the fish fry and fishermen who would be economically disadvantaged if the fish fry stalls were damaged because they would incur costs to transport their catch to another location or use cold storage facilities (Caribsave 2012). Subsistence farmers and small informal enterprises will be unable to cope with droughts, floods, landslides and infrastructure damage, in the absence of insurance coverage.
Small Island Developing States financing, poverty and climate change

The long-term effects of climate change in Caribbean SIDS are estimated to be at least $75 \%$ of GDP by 2100 in Dominica, Grenada, Haiti, St Kitts and Nevis and Turks and Caicos Islands (Caribbean Development Bank (CDB) 2015). Poverty levels continue to rise with $21 \%$ of the region's population living below the poverty line (CDB 2015). The impacts from climate variability, SLR and climate change have further exacerbated the decline in economic growth and rising unemployment. Unemployment is generally high across the sub-region and has intensified poverty and fuelled the expansion of the informal sector. Throughout the region, youth unemployment rates range between 18 and 47\% (United Nations Development Programme 2016). UNECLAC (2011) revealed that unless there is a meaningful adaptation and mitigation to climate change, the potential economic loss to the Caribbean region would be 2 to $3 \%$ of its GDP annually. The total loss due to inaction will amount to $22 \%$ of GDP for the Caribbean as a whole by 2100 . Given prevailing economic conditions in many Caribbean economies, poverty and unemployment will be exacerbated if temperature rises beyond $1.5^{\circ} \mathrm{C}$.

\section{Environmental vulnerability beyond $1.5^{\circ} \mathrm{C}$}

The Caribbean Region is one of 35 of the world's biodiversity hotspots and ranks third internationally in endemism so that it is exceptionally important for global biodiversity conservation. SIDS biodiversity and ecosystem services are strongly shaped by both local geography and social-ecological dynamics. If the $1.5^{\circ} \mathrm{C}$ temperature warming is exceeded, environmental resources will be at risk.

\section{Freshwater resources}

Freshwater supply in several SIDS has been a perennial challenge (Nurse et al. 2014). The geographical characteristics of some SIDS such as high volcanic islands with small, steep river catchments have a tremendous influence on water supply. These watersheds respond rapidly to rainfall events, but generally have limited storage capacity (Nurse et al. 2014). The past trends in the Caribbean revealed that over the last three decades, a significant increase in droughts and flooding has occurred. Non-climatic drivers such as land use, demographic, socioeconomic, weak water governance, technological and lifestyle changes have also impacted on SIDS freshwater systems (Mycoo 2007 and Mycoo 2011; Cashman 2012).

Beyond $1.5^{\circ} \mathrm{C}$ temperature increase, water supply will be endangered as more recent El Niño events, including 2015, proved to be the hottest year in recorded world history causing severe droughts. Projected impacts show that under the SRES 
A1B medium emissions scenario, the overall annual decrease in precipitation may be $12 \%$ (Nurse et al. 2014). If the Representative Concentration Pathway is considered, precipitation is expected to decrease by 5 to $6 \%$ by 2100 which will have implications for water security.

\section{Coral reefs}

A $1.5^{\circ} \mathrm{C}$ increase provides some chance for rebound potential in coral reef populations thereby increasing the potential for ecosystem adaptation (Graham et al. 2015). However, if the $1.5^{\circ} \mathrm{C}$ threshold is exceeded, coral reefs will be extremely vulnerable to temperature changes. Already more than $75 \%$ of the Caribbean's reefs are considered threatened by bleaching and intense hurricanes, with more than $30 \%$ in the high and very high threat categories (Burke et al. 2011). It is projected that by 2030 , climate-related threats will be high in the eastern Caribbean and will push the proportion of reefs at risk to $90 \%$ in 2030 , and up to $100 \%$ by 2050 , with about $85 \%$ at high, very high or critical levels. Virtually all tropical coral reefs are projected to be at risk of severe degradation due to temperature-induced bleaching Schleussner et al. (2016). This forecast has serious implications for the Caribbean's economic survival. The fisheries and tourism sectors are dependent on the survival of coral reefs. Moreover, tourism is a critical economic pillar for many nations, and for those with relatively poor agricultural or industrial sectors, it is one of the few available livelihoods. Estimates suggest that the economic value of Martinique and St. Lucia coral reefs comes to US $\$ 50,000$ per $\mathrm{km}^{2}$ per year (Burke et al. 2011).

\section{Wetlands and forests}

A temperature increase above $1.5{ }^{\circ} \mathrm{C}$ will pose a danger to mangrove forests especially if sea levels rise. Over the last quarter-century, mangrove forests have declined by $24 \%$ across the Caribbean, mostly due to coastal development (UNEP 2014). The region has the second highest mangrove area lost relative to other global regions (FAO 2007). Mangrove coverage has declined steadily over the past decades at the rate of approximately $0.08 \%$ per year (Hamilton and Casey 2016). However, the removal or weakening of these natural sea defences by changing land use is making the region's coastlines more susceptible to climate change impacts. Mangrove loss causes saline intrusion of freshwater reserves, erodes coasts and destroys wildlife habitats.

Increases in surface temperature are expected to affect the geographic range of mangrove species and disrupt the timing of flowering and fruiting. Sea level rise is a major potential climate change threat to mangrove ecosystems because mangroves are sensitive to changes in inundation duration and frequency as well as salinity levels that exceed a speciesspecific physiological threshold of tolerance (Friess et al.
2012). Increases in flooding duration can lead to plant death at the seaward mangrove margins as well as shifts in species composition, ultimately leading to a reduction in productivity (Castañeda-Moya et al. 2013) and ecosystem services. However, mangroves have considerable resilience to fluctuations in sea level due to their ability to actively modify their environment through surface elevation change processes, and their ability to migrate inland over successive generations (Krauss et al. 2013). This is a positive scientific finding for the defence of the Caribbean's urban settlements and infrastructure.

Forest destruction has occurred in Jamaica and Trinidad and Tobago where anthropogenic factors such as urban sprawl, informal settlements and forest fires account for this damage. However, in urban settlements where forest loss has occurred, flooding is common in the wetter rainy season and with the passage of hurricanes and storms associated with climate change. Beyond the $1.5^{\circ} \mathrm{C}$ threshold, higher precipitation and forest destruction by more intense hurricanes and storms are expected to cause greater flood damage in the Caribbean.

\section{Climate change refugees}

If climate-sensitive economic sectors are affected by crossing the $1.5^{\circ} \mathrm{C}$ temperature increase, Caribbean SIDS will produce climate change refugees who may be forced to migrate outside the region. The Caribbean may have among the world's highest numbers of environmental and economic refugees. Settlements in coastal locations make them highly vulnerable to climate change impacts such as SLR and flooding. The relocation of tens of thousands of 'climate change migrants' from coastal urban areas due to the consequences of natural hazards and climate change impacts is an increasing possibility for some countries such as Haiti, the Bahamas, Guyana, Suriname and Belize. Relocation is a challenge for governments of the region because of high associated social and economic costs.

\section{Adaptation strategies beyond $1.5^{\circ} \mathrm{C}$}

Caribbean SIDS have been at the forefront of utilising adaptation strategies to effectively respond to climate change through their active engagement in seeking solutions to direct and indirect losses resulting from SLR and more severe natural hazards. The region has tremendous experience in building coastal protective structures, using accommodation strategies and adopting retreat strategies. Moreover, in acknowledging financial resource constraints, the Caribbean with the aid of donor and multilateral lending agencies has developed techniques for prioritising, monitoring and evaluating adaptation measures. 
Despite international cooperation and regional collaboration, if the global temperature rises beyond the $1.5^{\circ} \mathrm{C}$ target set under the COP21, the Caribbean Region will need to act speedily, though cautiously, to redress the devastating consequences. Many of the existing adaptation strategies will be needed. This section of the paper discusses adaptation implications and options under a scenario of exceeding the $1.5^{\circ} \mathrm{C}$ target.

\section{Human settlements and coastal infrastructure adaptation strategies}

Each of the region's countries will need to make hard decisions on whether to defend, retreat or relocate capital cities from the coast if a $1.5^{\circ} \mathrm{C}$ temperature warming is crossed. In the first instance, the hold-the-line approach which acknowledges that urban settlements and critical infrastructure cannot be relocated or realigned away from the coast should be implemented if climate change impacts will occur in the short to medium term. Coastal engineering is both costly to construct and maintain as Barbados and Guyana have discovered (Mycoo and Chadwick 2012 and Mycoo 2014a). However, seawall defences are critical in the case of severe coastal erosion along the south-west coast of Barbados and severe flooding in Georgetown, Guyana, and immediate action is necessary (Mycoo and Chadwick 2012 and Mycoo 2014a). Under the $1.5^{\circ} \mathrm{C}$ scenario, a 'do nothing' approach is deemed inappropriate for cities that face high risks from SLR but where infrastructure and population are concentrated. Coastal structures will need to be built, monitored and evaluated over time.

Adaptation costs of building coastal defences will be exorbitant for Caribbean SIDS. Caribbean governments must build more than $322 \mathrm{~km}$ of levees and sea walls totalling almost US\$6 billion or the region will be in peril (Caribsave 2012). Countries in the region will have to urgently access climate funds depending on whether the temperature change is rapid. The Addis Ababa Financing for Development process made it clear that there was a need for a 'call to action' in support of SIDS (Mycoo and Donovan 2017). The immediacy of impending SLR will require that multilateral and bilateral lending agencies increase budgetary allocations to finance protective structures that will be a burden for SIDS economies (Mycoo and Donovan 2017). The European Commission in May 2017 pledged US\$900 million over the next 3 years up to 2020 to help the African, Caribbean and Pacific countries address climate change impacts (Inter Press Service 2017).

In the second instance, Caribbean nations will need to revisit spatial strategies that have fostered a high concentration of population in the LECZ. A more balanced settlement system that encourages a reversal of the primate city 'syndrome' and stimulates the development of a system of secondary urban centres away from the coast is critical in adapting to SLR
(Mycoo and Donovan 2017). SIDS such as Dominica, St. Vincent and St. Kitts are now embarking on the preparation of national spatial development plans which makes it timely to incorporate climate change policies. Additionally, although National Adaptation Programmes of Action (NAPAs) have become a principal way of organising adaptation priorities in SIDS, most plans do not explicitly include urban projects and do not reflect local government perspectives (Mycoo and Donovan 2017). NAPAs should have a greater urban settlement focus and incorporate local government inputs so as to ensure buy-in of these plans.

Retreating from the coast either by relocation or managed realignment may be imperative in some extreme cases or worst-case scenarios. Relocation may be entirely justifiable where cities are highly vulnerable to the smallest increment in SLR such as Georgetown and Paramaibo. This precedent has occurred in the region; Belmopan serves as an example of a capital city relocated to a safer interior location in 1970 following the devastation of Belize City by Hurricane Hattie. Unlike continental-based SIDS with large land masses and low population densities such as Belize, Guyana and Suriname, small highly vulnerable islands, however, will need to make far more difficult decisions. Rigorous social-cost benefit analysis is recommended to guide decision-making regarding relocation and social displacement of population (Mycoo and Donovan 2017), but as López-Carr and MarterKenyon (2015) argue, institutional and legal systems remain ill prepared for managing relocation in response to climate threats and this is observation applies to Caribbean SIDS.

The Caribbean building code has not been officially accepted but is nevertheless being implemented by the region's engineering profession (Mycoo and Donovan 2017). Building codes allow in situ upgrading of structures and sites. These should include building standards such as the use of stilts or elevated floors which was historically the practice in floodprone areas such as Georgetown (Guyana) and Chaguanas (Trinidad). Hurricane-resistant building codes and site development standards for flood proofing need to be enforced. Furthermore, informal housing in the region does not adhere to either building codes or site development guidelines. A system of incentivisation such as subsidies on building materials should be introduced to encourage compliance among informal dwellers. Proposed improvements also include greater use of the Tree Preservation Order which is an integral part of the Town and Country Planning Act of English-speaking Caribbean countries. This legislation enhances flood mitigation.

To address increasing temperatures, Caribbean architecture should return to the use of the vernacular design where buildings were more energy efficient and better adapted to enhance natural ventilation and cooling as opposed to the current use of air conditioning. Urban planners also have a key role to play in promoting the use of green infrastructure in cities to lower 
urban heat island impacts. The Tree Preservation Order should be stringently enforced and more open space including urban parks should be preserved.

\section{Integrated coastal zone management and coastal setbacks}

Retreating from the coastline to protect settlements and infrastructure has been implemented in some Caribbean SIDS which have adopted coastal setbacks while in others legislation dating back to the colonial era has been applied to protect settlements (Mycoo 2005). In some SIDS such as Barbados, the Dominican Republic and Cuba coastal setbacks are employed, but in several islands enforcement is weak and large private developers may appeal the decisions of physical planning agencies. Lessons may be distilled from Cuba which has a strong legislative coastal zone management plan that is relatively simple to apply (Simpson et al. 2012) and Barbados where ICZM has been enacted and successfully implemented (Mycoo 2014b; Mycoo and Chadwick 2012). St. Lucia and Tobago use colonial legislation that prohibits built development in designated coastal reserves with setbacks from the high water mark (Mycoo 2005). Caribbean SIDS have been at the forefront in using coastal setbacks (Mycoo 2014b) which will now augur well for combatting climate change beyond the $1.5^{\circ} \mathrm{C}$ target.

The establishment of Integrated Coastal Zone Management Units (ICZMU), which would help frame national guidelines on coastal management and beach restoration within each island, is recommended. Furthermore, international development agencies can play an instrumental role in funding studies on coastal dynamics and data collection which are integral to the establishment and functioning of an ICZMU. One such project initiated in the Bahamas aims to build upon the improvements contained in the 2010 Planning and Subdivisions Act (Mycoo and Donovan 2017). A risk-based ICZM was also established to assist the Bahamas meet the target of $20 \%$ conservation of the nearshore environment by 2020 (Mycoo and Donovan 2017).

\section{Health}

Caribbean Member States can use the Paris Agreement commitments on climate change and hold to the $1.5{ }^{\circ} \mathrm{C}$ for three purposes (World Health Organisation 2016): (i) to strengthen the climate resilience of their health systems, for example through improved disease surveillance and preparedness for extreme weather events, ensuring climate-resilient health facilities, with access to essential services such as energy, water and sanitation; (ii) to identify and promote measures that both reduce climate pollution and improve health, for example through reducing air pollution, and by reducing the environmental impact of the health sector itself; and (iii) to access the financial support mechanisms for climate action, to support the above objectives. However, less than $1.5 \%$ of international finance for climate change adaptation is currently allocated to health projects (World Health Organisation 2016). The Caribbean Environmental Health Institute recommended establishing monitoring and surveillance systems, creating an enabling environment, strengthening the public health infrastructure, promoting research and promoting awareness and education (Ebi et al. 2006). Greater effort is needed by Caribbean SIDS to access the Green Climate Fund and Adaptation Fund to simultaneously promote air quality and reduce emissions of warming climate-altering pollutants. Recent research by Hondula et al. (2015) on the impact of rising temperature on human health and potential adaptation options provide interesting insights that are relevant to adaptation in Caribbean SIDS.

\section{Ecosystem-based adaptation}

Ecosystem-based adaptation (EBA) should be actively promoted to protect coastal and terrestrial areas should the $1.5^{\circ} \mathrm{C}$ target be exceeded. Projected increases in carbon dioxide and temperature over the next 50 years will stress coral reefs because they exceed the conditions under which they have flourished over the past half-million years, but some corals are showing resiliency to climate change impacts and should be used where reefs have been damaged (Hughes 2009). Reefs will change rather than disappear entirely, with some species already showing far greater tolerance to climate change and coral bleaching than others. The designation of marine protected areas is recommended to protect remaining coral reefs in the region.

Forest management can also assist in replenishing water resources by reducing surface water runoff and improve carbon sequestration. Under drought conditions, forests will be a major role as part of integrated water resources management (IWRM). International efforts should be vigorously implemented and complemented by robust policy decisions to reduce global warming.

Some initiatives have started to address EBA such as the German Ministry for Economic Cooperation and Development which is supporting CARICOM through the financing of a project on Coastal Protection for Climate Change Adaptation in the Small Island States in the Caribbean. The project focuses on the implementation of local adaptation measures for the sustainable improvement of coastal ecosystems relevant for climate change adaptation in Saint Lucia, Grenada, St. Vincent and the Grenadines and Jamaica (Caribbean Community Climate Change Centre (CCCCC) 2017a).

\section{Economic diversification}

The region should diversify its economic base and reduce its dependency on single sectors such as tourism, agriculture or 
fisheries. These are already highly sensitive and will become hypersensitive beyond $1.5^{\circ} \mathrm{C}$. The Caribbean has been branded mainly as a coastal tourism destination but with the possibility of temperature warming beyond $1.5^{\circ} \mathrm{C}$, significant loss of coral reefs and beaches is expected. Coastal structures to protect beaches will be aesthetically unpleasing and costly beach nourishment will be unfeasible. Terrestrial-based tourism promoting the rainforest and heritage tourism should be marketed as alternatives to coastal tourism that may stabilise SIDS economies and reduce the potential to create economic refugees. Much remains to be done to understand how tourism and the destinations in which it operates can prosper in the increasingly changed climate of the twenty-first century (Scott et al. 2016b; Scott et al. 2016c).

There is a high overall potential for the Caribbean's tourism industry to fund its climate change adaptation even with a $1.5^{\circ} \mathrm{C}$ temperature warming. Adaptation taxes and levies, adaptation funds, building regulations and risk transference are funding mechanisms. However, there are significant challenges in realising these potential funding mechanisms and regulations (Hess and Kelman 2017). Many Caribbean countries have not yet explored adaptation taxes and levies, but starting in September 2017, the British Virgin Islands will pioneer the use if a US $\$ 10$ per tourist levy for climate change adaptation (Government of the British Virgin Islands 2017). However, cruise ship passengers will be exempted from this tax.

\section{Freshwater resources and water security}

SLR associated with temperatures that exceed $1.5^{\circ} \mathrm{C}$ will cause increased salinity in estuarine and aquifer water, affecting ground and surface water resources of drinking and irrigation water. Drought-proofing Caribbean SIDS will involve the use of technology, land-use planning and ecosystem-based adaptation policies. Water scarce countries in the Caribbean have already started adapting to climate change by implementing projects and revising water management approaches and policies. Desalination is not new to the Caribbean and has had mixed success in small island settings owing to operational costs (White and Falkland 2010), but extracting clean water from seawater is becoming an increasingly integral part of the region's search for water security.

Rainwater harvesting (RHW) will be important as alternative supplies of potable water (White and Falkland 2010) and for disaster risk reduction. Following extreme, destructive weather events such as hurricanes and tropical storms, damage to water infrastructure and contamination of water supplies may occur. While there may also be some damage to RWH systems, because these are decentralised, there is the probability that some would remain operational and allow access to water for sanitation and, if properly treated, for consumption.
SIDS will also need to consider other policy measures to assist them in adapting to water scarcity associated with climate change. The Town and Country Planning Department of Barbados requires all buildings, other than houses having a gross roof area of $93 \mathrm{~m}^{2}$ or more, to install a rainwater storage tank or cistern for secondary uses (Mycoo 2006). It is also mandatory that hotels have on-site water-recycling facilities for golf courses and landscaped areas. The regulations should apply to all new buildings (Mycoo 2006). These measures in addition to a tax rebate incentive may also be applied to new developers in other SIDS, but they should meet the minimum site development standards and recycling requirements.

Several countries have also adopted IWRM to protect water resources. The IWRM process promotes the coordinated development and management of water, land and related resources in order to maximise economic and social welfare in an equitable manner without compromising the sustainability of vital ecosystems. This process has been challenging in the region, but the approach must be actively implemented if countries are to overcome water shortages should temperature rise beyond $1.5^{\circ} \mathrm{C}$. In addition, the Caribbean Water, Climate and Development Programme should be actively pursued to respond to eminent water droughts that have been forecasted.

\section{Disaster risk reduction}

A temperature increase beyond the $1.5^{\circ} \mathrm{C}$ is expected to increase the intensity of natural hazards in the region. Disaster risk reduction (DRR) is fundamental to adaptation. A list of DRR measures includes land-use zoning, hurricane-resistant buildings, building codes, hazard mapping and early warning systems. Increasing the Caribbean Catastrophe Risk Insurance Facility will be necessary to cover more projected damage. Also, a coastal risk atlas should be done for each country to enhance the decision-making capacity of physical planners to determine site suitability for development.

Under the $1.5^{\circ} \mathrm{C}$ scenario, the poor may become more marginalised and highly prone to disasters because of a lack of resources. Many disadvantaged households depend on remittances from overseas family members, access funds from indigenous pooled savings such as the Sou Sou (Trinidad) or Partner (Jamaica) or credit unions (Mycoo 2017). Alternative sources of informal financing can be tapped to encourage compliance with safety regulations by poor households which may help lower their exposure to risks and consequently facilitate their economic recovery.

\section{Financing beyond $1.5^{\circ} \mathrm{C}$}

More international funding for adaptation and mitigation is being committed, largely as official development assistance, and governments are broadly on track delivering on their international promises, such as the Cancun Agreements, to scale 
up international climate finance. The members of the OECD Development Assistance Committee reported that the agency committed approximately US $\$ 2$ billion in total adaptation financing to SIDS across all sectors between 2010 and 2014. This was roughly $6 \%$ of the total committed to all developing countries (Robinson and Dornan 2016). Ten SIDS received $73 \%$ of total adaptation financing between 2010 and 2014. Caribbean SIDS received the most funding $(41 \%)$ in contrast to the Pacific (36\%) and the Africa, Indian Ocean, Mediterranean and South China Sea SIDS (23\%) from 2010 to 2014 (Mycoo and Donovan 2017). Additionally, aid to SIDS is increasingly channelled through multilateral development banks, including the Inter-American Development Bank which has financed US\$200 million in more than 50 programmes in coastal city adaptation and improved urban planning in Caribbean SIDS to protect vulnerable human settlements (Mycoo and Donovan 2017). Despite the commitment of funding to Caribbean SIDS, bureaucratic bottlenecks restrict the trickling down of funds to communities most in need of protection against climate change impacts. Constraints in accessing funding by poor communities need to be urgently addressed. Some steps are in place as for example, in 2017, the CCCCC received funds from the Green Climate Fund to implement a project on institutional strengthening in Belize and the Bahamas (Caribbean Community Climate Change Centre (CCCCC) 2017b). It involves capacity building of a National Designated Authority to prepare country strategic frameworks for mitigation and adaptation (Caribbean Community Climate Change Centre (CCCCC) 2017b). The lessons from this project should be scaled-up regionally. Additionally, Caribbean SIDS have not fully explored debt-for-nature swaps, but this innovative financing method may be used to help establish marine protected areas and forest reserves and facilitate mangrove restoration as part of climate change adaptation to the potential impacts if temperatures rise beyond $1.5^{\circ} \mathrm{C}$.

Drawing from the author's knowledge and experience working throughout the Caribbean, financing for adaptation and resiliency building is important and urgent. Without finance, the adaptation of human settlements, coastal infrastructure, the economy, ecosystems and governance if temperature rises above $1.5{ }^{\circ} \mathrm{C}$ will be impossible. Technology and data acquisition, capacity building and behavioural change, though important, are less urgent and are long-term on-going activities.

\section{Resiliency}

The Caribbean has been resilient historically and will need to accelerate adaptive capacity and resiliency in the face of climate change challenges accompanying temperature increase beyond $1.5{ }^{\circ} \mathrm{C}$. The author found from research in the Caribbean that resiliency building is urgent if human settlements, coastal infrastructure, the economy, ecosystems and governance systems are to cope with threats that are likely to accompany a temperature increase beyond $1.5{ }^{\circ} \mathrm{C}$. To strengthen resiliency in the future, land-use planning, promoting compact urban form, using building codes, upgrading infrastructure, developing green infrastructure and EBAs, reducing disaster risk, building institutional capacity and effective urban governance, building capabilities for data acquisition, monitoring and evaluating results, and exploring an array of financial instruments to mobilise fiscal resources will be fundamental. Resilience is the product of successful adaptation stemming from the collective action of governments, enterprises, civil society organisations, households and individuals with strong adaptive capacity. In the Caribbean, households and individuals, especially economically disadvantaged ones, have consistently demonstrated resilience in the aftermath of disasters. They have been self-reliant and have not depended on government assistance, which is often protracted, and a bureaucratic maze which poor households are unable to navigate. Climate change impacts beyond $1.5^{\circ} \mathrm{C}$ will, however, further test the resilience of the Caribbean's population, governments and institutions. Such impacts threaten to overwhelm the resilience of stakeholders and existing systems.

Institutional barriers to effective adaptation will need to be removed if temperature rises beyond $1.5^{\circ} \mathrm{C}$. Barriers can be overcome with concerted effort, creative management, change of thinking, prioritisation and related shifts in resources, land uses and institutions (Moser and Estrom 2010). Many seeming limits, especially social ones, are in fact malleable barriers; they can be overcome with sufficient political will, social support, resources and effort (Adger et al. 2009). However, many barriers will make adaptation less efficient or less effective or may require costly changes that lead to missed opportunities or higher costs (Moser and Estrom 2010). Not questioning the changeability of such barriers (however difficult to overcome) may itself be an obstacle to progressing in the adaptation process (Moser and Estrom 2010). Transformational change is recommended to challenge the systems and structures, economic and social relations, and beliefs and behaviours that contribute to climate change and social vulnerability.

\section{Conclusion}

The Caribbean is in the frontline of severe climate change impacts more than many other parts of the world because of its geographic location as most regional states are smaller islands where people live close to and depend on the sea for economic survival. As biodiversity hotpots, Caribbean ecosystems are highly sensitive to impacts at $1.5^{\circ} \mathrm{C}$ and beyond and many risks may amplify each other to produce cascading impacts that further filter through ecosystems and penetrate socio-economic systems. The Caribbean has been innovative 
in adapting to climate change and many adaptation approaches currently used remain relevant. The new challenge will be how to resource, scale up and accelerate implementation of these strategies if temperature warming exceeds $1.5^{\circ} \mathrm{C}$. Prioritising practical adaptation options is essential for Caribbean SIDS given limited human, technical and financial resource capacity. Some adaptation strategies are more urgent than others and should be made a top priority. However, adaptation action should be guided by each country's unique characteristics and informed by citizen science or run the risk of maladaptation. Governments of the region need to prepare and protect their societies, economies and environments from impending change associated with exceeding the $1.5^{\circ} \mathrm{C}$ target. Transformative adaptation and resiliency building are critical in the context of temperature warming beyond $1.5^{\circ} \mathrm{C}$.

\section{References}

Adger WN, Dessai S, Goulden M, Hulme M, Lorenzoni I, Nelson DR, Naess LO, Wolf J, Wreford A (2009) Are there social limits to adaptation to climate change? Climate Change 93:335-354. https://doi.org/10.1007/s10584-008-9520-Z

Bueno R, Stanton E, Ackerman F (2008) The Caribbean and climate change: the cost of inaction. The environmental defense fund. http://ase.tufts.edu/gdae/pubs/rp/caribbean-full-eng.pdf. Accessed 3 April 2017

Burke L, Reytar K, Spalding M, Perry A (2011) Reefs at risk revisited. World Resources Institute, Washington DC www.wri.org/ publication/reefs-risk-revisited. Accessed 18 September 2017

Caribbean Community Climate Change Centre (CCCCC) (2017a) 20142018 Coastal protection for climate change adaptation in the small island states in the Caribbean. http://www.caribbeanclimate.bz/ ongoing-projects/2014-2019-coastal-protection-for-climate-changeadaptation-in-the-small-island-states-in-the-caribbean-kfw.html. Accessed 19 August 2017

Caribbean Community Climate Change Centre (CCCCC) (2017b) Consultancy for capacity building of national designated authority (NDA) and country strategic framework, Belize and the Bahamas. https://caribbeanclimateblog.com/2017/08/09/consultancy-forcapacity-building-of-national-designated-authority-nda-andcountry-strategic-framework-belize-and-the-bahamas/. Accessed 12 August 2017

Caribbean Development Bank (CDB) (2015) CDB to help countries gather poverty data more effectively. Bridgetown. www.caribank.org/ news/cdb-to-help-countries-gather-poverty-data-more-effectively. Accessed 18 September 2017

Caribsave (2012) Climate change risk profile for Barbados. Caribbean Regional Headquarters. Bridgetown. www.caribsave.org/assets/ files/CCCRA. Accessed 20 May 2017

Cashman AC (2012) Water policy development and governance in the Caribbean: an overview of regional progress. Water Policy 14:14 30. https://doi.org/10.2166/wp.2011.122

Castañeda-Moya E, Twilley R, Rivera-Monroy V (2013) Allocation of biomass and net primary productivity of mangrove forests. For Ecol Manag 307:226-241. https://doi.org/10.1016/j.foreco.2013.07.011

Centre for Research on the Epidemiology of Disasters (CRED) (2015) EM-DAT Natural Disaster-Caribbean Database. http://www. emdat.be/database. Accessed 6 May 2017
Church J, Clark P, Cazenave A, Gregory J, Jevrejeva S, Levermann A, Merrifield M, Milne G, Nerem R, Nunn P, Payne A, Pfeffer W, Stammer D, Unnikrishnan A (2013) Sea level change. Climate change 2013: The physical science basis. Contribution of Working Group I to the Fifth Assessment Report of the Intergovernmental Panel on Climate Change. Cambridge University Press, Cambridge. https://www.ipcc.ch/pdf/assessmentreport/ar5/wg1/WG1AR5 Chapter13 FINAL.pdf. Accessed 30 Oct 2017

Ebi KL, Lewis ND, Corvalan C (2006) Climate variability and change and their potential health effects in small island states: information for adaptation planning in the health sector. Environ Health Perspect 114(12):1957-1963. https://doi.org/10.1289/ehp.8429

Food and Agriculture Organization (2007) The world's mangroves 1980 2005. A thematic study prepared in the framework of the global forest resources assessment 2005. Forestry Paper 153. Rome. ftp:// ftp.fao.org/docrep/fao/010/a1427e/a1427e00.pdf. Accessed 12 April 2017

Friess D, Krauss K, Horstman E, Balke T, Bourna T, Galli D, Webb E (2012) Are all intertidal wetlands naturally created equal? Bottlenecks, thresholds and knowledge gaps to mangrove and saltmarsh ecosystems. Biol Rev 87:346-366. https://doi.org/10. 1111/j.1469-185X.2011.00198.x

Government of the British Virgin Islands (2017) www.bvitourism.com/ news/environmental-levy-takes-effect-september-Accessed 12 August 2017

Government of Jamaica (GOJ) (2015) Statement on drought conditions and impact on the agricultural sector. Ministry of Agriculture and Fisheries, Kingston http://jis.gov.jm/statement-drought-conditionsimpact-agricultural-sector/

Graham NAJ, Jennings S, Macneil M, Mouillot D, Wilson S (2015) Predicting climate-driven regime shifts versus rebound potential in coral reefs. Nature 518:94-97. https://doi.org/10.1038/nature14140

Hallegatte S, Green C, Nicholls R, Corfee-Morlot J (2013) Future flood losses in major coastal cities. Nat Clim Chang 3:802-806. https:// doi.org/10.1038/nclimate1979

Hamilton S, Casey D (2016) Creation of a high spatiotemporal resolution global database of continuous mangrove forest cover for the $21 \mathrm{st}$ century. Glob Ecol Biogeogr 25(6):729-738. https://doi.org/10. 1111/geb.12449

Hess JS, Kelman I (2017) Tourism industry financing of climate change adaptation: exploring the potential in small island developing states. Clim Disaster Dev J 2(2):33-45. 10.18783/cddj.v002.i02.a04

Hondula DM, Balling RC, Vanos JK, Geogescu M (2015) Rising temperature, human health and the role of adaptation. Curr Clim Change Rep 1(3):265-267. https://doi.org/10.1007/s40641-015-0016-4

Hughes T (2009) Confronting the global decline of coral reefs. In: Duarte C M (eds) Global Loss of Coastal Habitats: Rates Causes and Consequences. https://w3.grupobbva.com/TLFU/dat/00\% 20Duarte_Separata.pdf

Inter Press Service (2017) Europe stands by Caribbean in Climate Change Funding http://www.ipsnews.net/2017/06/europe-stands-caribbeanclimate-funding/. Accessed 12 August 2017

International Monetary Fund (IMF) (2008) Measuring the informal economy in Latin America and the Caribbean. Washington, DC. https:// www.imf.org/en/Publications/WP/Issues/2016/12/31/Measuringthe-Informal-Economy-in-Latin-America-and-the-Caribbean21898. Accessed 2 May 2017

International Monetary Fund (2016) Policy paper: Small States' resilience to natural disasters and climate change. International Monetary Fund, Washington, DC https://www.imf.org/external/np/pp/eng/ 2016/110416.pdf. Accessed 22 March 2017

International Union for Conservation of Nature (2015) Blue solutions from Latin America and the wider Caribbean. https://www.iucn. org/content/blue-solutions-latin-america-and-wider-caribbeanregion. Accessed 29 May 2017 
Jury M, Winter A (2010) Warming of an elevated layer over the Caribbean. Climate Change 99:247-259. https://doi.org/10.1007/ s10584-009- 9658-3

Krauss K, McKee K, Lovelock C, Cahoon D, Saintilan N, Reef R (2013) How mangrove forests adjust to rising sea level. New Phytol 202: 19-34. https://doi.org/10.1111/nph.12605

López-Carr D, Marter-Kenyon J (2015) Human adaptation: manage climate-induced resettlement. Nature 1517(7534):265-267. https:// doi.org/10.1038/517265a

Mahon R, Becken S, Rennie HG (2013) Evaluating the business case for investment in the resilience of the tourism sector of small island developing states. Lincoln University (Canterbury N.Z.); Lincoln University, Christchurch http://researcharchive.lincoln.ac.nz/ dspace/bitstream/10182/5300/3/LEaP_rr_32.pdf

Mimura N, Nurse LA, McLean RF, Agard J, Briguglio L, Lefale P, Payet R, Sem G (2007) small islands. In: Climate change 2007: impacts, adaptation and vulnerability. Contribution of working group II to the fourth assessment report of the intergovernmental panel on climate. Cambridge University press, Cambridge, pp 687-716 https://www. ipcc.ch/pdf/assessment-report/ar4/wg2/ar4-wg2-chapter16.pdf. Accessed 15 September 2017

Moser SC, Estrom JA (2010) A framework to diagnose barriers to climate change adaptation. Proc Natl Acad Sci USA 107(51):22026-22031. https://doi.org/10.1073/pnas.1007887107

Mycoo M (2017) A Caribbean new urban agenda post-habitat III: closing the gaps. Habitat Int 69:68-67. https://doi.org/10.1016/j.habitatint. 2017.09.001

Mycoo M, Donovan MG (2017) A blue urban agenda: adapting to climate change in the coastal cities of Caribbean and Pacific Small Island Developing States. IDB, Washington https://publications. iadb.org/handle/11319/8264. Accessed 20 May 2017

Mycoo M (2014a) Autonomous household responses and urban governance capacity building for climate change adaptation. Georgetown, Guyana. Urban Clim 9:134-154. https://doi.org/10.1016/j.uclim. 2014.07.009

Mycoo M (2014b) Sustainable tourism, climate change and sea level rise adaptation policies: Barbados. Nat Res Forum 38(1):47-51. https:// doi.org/10.1111/1477-8947.12033

Mycoo M, Chadwick A (2012) Adaptation to climate change: the coastal zone of Barbados. Marit Eng 165(4):159-168. https://doi.org/10. 1680/maen.2011.19

Mycoo M (2011) Conflicting objectives of Trinidad's water pricing policy: a need for good water pricing and governance. Int J Water Res Dev 27(4):723-736. https://doi.org/10.1080/07900627.2011. 619899

Mycoo M (2007) Diagnosis of Trinidad's water problems (mid-1980s to mid-1990s). Water Policy 9(1):73-86. https://doi.org/10.2166/wp. 2006.062

Mycoo M (2006) Sustainable tourism using regulations, market mechanisms and green certification: a case study of Barbados. J Sustain Tour 14(5):489-511. https://doi.org/10.2167/jost600.0

Mycoo M (2005) Minimising foreign control of land: a case study of St. Lucia. Land Use Policy 22:345-357. https://doi.org/10.1016/j. landusepol.2004.06.003

Neira, M and L.A. Galvão (2013) in World Health Organisation (2013) Protecting Health from Climate Change Vulnerability and Adaptation Assessment. Preface. http://apps.who.int/iris/bitstream/ 10665/104200/1/9789241564687_eng.pdf. Accessed 30 October 2017

Nurse L (2011) Caribbean fisheries are highly vulnerable to climate change and need to adapt. Stockholm Environment Institute. https://www.ipcc.ch/pdf/assessment-report/ar5/wg2/WGIIAR5Chap29 FINAL.pdf. Accessed 30 April 2017

Nurse L, McLean R, Agard J, Briguglio L, Duvat-Magnan V, Pelesikoti N, Tompkins E, Webb A (2014) Small islands. In: Climate Change 2014: Impacts, adaptation, and vulnerability. Part B: Regional
Aspects. Contribution of Working Group II to the Fifth Assessment Report of the Intergovernmental Panel on Climate Change. Cambridge University Press, Cambridge, pp 1613-1654

Patil P, Virdin J, Diez S, Roberts SA (2016) Toward a blue economy: a promise for sustainable growth in the Caribbean; an overview. The World Bank, Washington DC https://openknowledge.worldbank. o r g/b i t s tre a m/h a n d 1 e/10986/25061/ Demystifying0t0the0Caribbean0Region.pdf? sequence $=4$. Accessed 18 April 2017

Peters A (2017) Estimating the size of the informal economy in Caribbean States. IDB Technical Note 1248, Washington DC. https:// publications.iadb.org/.../Estimating-the-size-of-the-informaleconomy-in-Carib..

Rietbroek R, Brunnabend S, Kusche J, Schroter J (2012) Resolving sea level contributions by identifying fingerprints in time-variable gravity and altimetry. J Geodyn 59:72-81. https://doi.org/10.1016/j.jog. 2011.06.07

Robinson S, Dornan M (2016) International financing for climate change adaptation in Small Island Developing States. Reg Environ Chang 17(4):1103-1115. https://doi.org/10.1007/s10113-016-1085-1

Schleussner C, Lissner T, Fischer E, Wohland J, Perrette M, Golly A, Rogelj J, Childers K, Schewe J, Frieler K, Mengel M, Hare W, Schaeffer M (2016) Differential climate impacts for policyrelevant limits to global warming: the case of $1.5^{\circ} \mathrm{C}$ and $2{ }^{\circ} \mathrm{C}$. Earth Syst Dynam 7:327-351. https://doi.org/10.5194/esd-7-3272016

Shakeela A, Becken S (2015) Understanding tourism leaders' perceptions of risks from climate change: an assessment of policy-making processes in the Maldives using the social amplification of risk framework (SARF). J Sustain Tour 23(1):65-84. https://doi.org/10.1080/ 09669582.2014.918135

Scott D, Hall CM, Gössling S (2016a) A report on the Paris Climate Change Agreement and its implications for tourism: why we will always have Paris. J Sustain Tour 24(7):933-948. https://doi.org/10. 1080/09669582.2016.1187623

Scott D, Gossling S, Hall CM, Peeters P (2016b) Can tourism be part of the decarbonized global economy? The costs and risks of alternate carbon reduction policy pathways. J Sustain Tour 24(1):52-72. https://doi.org/10.1080/09669582.2015.1107080

Scott D, Hall CM, Gossling S (2016c) A review of the IPCC 5th assessment and implications for tourism sector climate resilience and decarbonization. J Sustain Tour 24(1):8-30. https://doi.org/10. 1080/09669582.2015.1107080

Scott D, Simpson M, Sim R (2012) The vulnerability of Caribbean coastal tourism to scenarios of climate change related sea level rise. J Sustain Tour 20:883-898. https://doi.org/10.1080/09669582.2012. 699063

Simpson M, Clarke C, Clarke J, Scott D, Clarke A (2012) Coastal setbacks in Latin America and the Caribbean. Inter-American Development Bank. https://publications.iadb.org/bitstream/handle/11319/5567/ Coastal\%20Setbacks\%20in\%20Latin\%20America\%20and\% 20the $\% 20$ Caribbean.pdf? sequence $=1$. Accessed 20 April 2017

Simpson M, Scott D, Trotz U (2011) Climate change's impact on the Caribbean's ability to sustain tourism, natural assets, and livelihoods. Inter-American Development Bank, Washington, DC http:// www.uncclearn.org/sites/default/files/inventory/idb14.pdf. Accessed 18 May 2017

Simpson M, Scott D, Harrison M, Silver N, O'Keeffe E, Harrison S, Taylor M, Sim R, Lizcano G, Wilson M, Rutty M, Stager H, Oldham J, New M, Clarke J, Day O, Fields N, Georges J, Waithe R, McSharry P (2010) Quantification and magnitude of losses and damages resulting from the impacts of climate change: modelling the transformational impacts and costs of sea level rise in the Caribbean. United Nations Development Programme, Bridgetown

Stern N (2016) Economics: current climate models are grossly misleading. Nature 530(7591):407-409 https://www.nature.com/polopoly_ 
fs/1.19416!/menu/main/topColumns/topLeftColumn/pdf/530407a (corrected).pdf. Accessed 18 September 2017

Tschakert $\mathrm{P}(2015) 1.5^{\circ} \mathrm{C}$ or $2^{\circ} \mathrm{C}$ : a conduit's view from the sciencepolicy interface at COP20 in Lima, Peru. Clim Change Res 2(1): 17. https://doi.org/10.1186/s40665-015-0010-z

United Nations Development Programme (2016) Human Development Report. United Nations Development Programme, Port of Spain

United Nations Economic Commission for Latin America and the Caribbean (UNECLAC) (2011) Saint Lucia macro socio-economic and environmental assessment of the damage and losses caused by hurricane Tomas: A geo-environmental disaster: towards resilience. United Nations Development Programme

United Nations Environmental Programme (2014) The importance of mangroves to people: a call to action. In: van Bochove J, Sullivan E, Nakamura T (eds) . United Nations Environment Programme
World Conservation Monitoring Centre, Cambridge https://www. unep-wcmc.org/.../the-importance-of-mangroves-to-people-a-callto-acti... Accessed 18 September 2017

White I, Falkland T (2010) Management of freshwater lenses in small Pacific islands. Hydrogeol J 18(1): 227-246. doi: https://doi.org/10. 1007/s10040-009-0525-0

World Health Organisation (2016) Health and Climate Change http:// apps.who.int/gb/ebwha/pdf_files/EB139/B139_6-en.pdf Accessed 9 August 2017

World Travel and Tourism Council (WTTC) (2015) Economic impact of tourism in the Caribbean. World travel and tourism council, London https://www.wttc.org/-/media/files/reports/economic\%20impact\% 20research/regional\%202015/caribbean2015.pdf. Accessed 18 September 2017 